\title{
Mergin Firms' Strategies and the Merger Paradox
}

\author{
Estratégias de Empresas Fundidas e o Paradoxo das Fusões
}

José Méndez-Naya (1)

(1) Universidade da Coruña

\begin{abstract}
Taking a model of horizontal mergers as a reference, the purpose of this paper is to qualify the merger paradox by proving that a multidivisional firm formed by a merger could be sustainable even though the merger does not involve most of the firms in the market. Specifically, it is proved that the minimum number of merging firms to have a profitable merger, assuming both simultaneous and sequential games, is lower in our model than in the traditional literature. Furthermore, it is proved that, if the multidivisional firm sets the number of divisions optimally, the merger is sustainable and less harmful to welfare than in the traditional model.
\end{abstract}

\section{Keywords}

mergers; multidivisional firms; firms' strategies.

JEL Codes L13; L23; L41.

\section{Resumo}

Tomando como referência um modelo de fusões horizontais, o objetivo deste artigo é qualificar o paradoxo das fusões, provando que uma empresa multidivisional formada por uma fusão poderia ser sustentável, embora a fusão não inclua a maioria das empresas do mercado. Especificamente, é testado que o número mínimo de empresas fundidas para ter uma fusão lucrativa, assumindo jogos simultâneos e sequenciais, é menor em nosso modelo do que no modelo tradicional Salant et al. (1983). Além disso, se prova que, se a empresa multidivisional a empresa estabelece de maneira ótima o número de subsidiárias, a fusão é sustentável e menos prejudicial ao bem-estar do que no modelo tradicional.

\section{Palavras-chave}

fusões; empresas multidivisionais; estratégias de empresas.

Códigos JEL L13; L23; L41. 


\section{Introduction}

The theoretical literature on horizontal mergers states that, in quantitysetting games assuming linear demand and costs and symmetric firms, a merger is not typically profitable for the merging firms unless it involves the vast majority of industry participants (Salant et al., 1983); this result could represent the first part of the merger paradox. Furthermore, a merger usually reduces the aggregate welfare, because it reduces the number of firms in the market and therefore decreases the existing market competition.

These theoretical results defy the empirical evidence (the wave of merger activity has increased throughout this century), and, at the same time, they are awkward for many economists (most mergers ought to be profitable), because, apart from the possible efficiency gains derived from a merger (Perry and Porter, 1985), the merged entity gains both market power which it should be able to exploit in a beneficial manner - and informational benefits (Creane and Davidson, 2004; Daughety, 1990; Huck et al., 2004).

Many authors have tried to solve the merger paradox using symmetric information models, by changing some of the assumptions of the original Salant et al. (1983) model: Fauli-Oller (1997) and (2000); González-Maestre and López-Cuñat (2001); and Perry and Porter (1985). Other authors have developed their analysis by assuming asymmetric information between firms: Daughety (1990); Escrihuela-Villar and Fauli-Oller (2008); and Huck et al. (2004). Creane and Davidson (2004) and Huck et al. (2004) assumed symmetric information between merging and non-merging firms but asymmetric information between the merging firms in the merged entity. Méndez-Naya (2014) considered asymmetric information between merging and non-merging firms.

Taking Creane and Davidson (2004) and Huck et al. (2004) as a reference, it is assumed that firms do not just become bigger through mergers but that they also become more complex organizations. Specifically, it is supposed that the multidivisional firm formed by a merger can exploit certain strategic possibilities that are inherent from having distinct divisions.

The purpose of this paper is to complement the existing literature on the subject by providing a model of horizontal mergers in which mergers are profitable for the merging firms even if they do not include most of the firms in the industry. Furthermore, it is justified that a merger is less harmful from a welfare point of view than in traditional models. 
To perform the analysis, basing on the basic Salant et al. (1983) model, let us set an oligopoly model in which there are $n$ firms. It is assumed that $k$ firms, being $k$ lower than $n$, decide to merge and, following Creane and Davidson (2004) and Huck et al. (2004), that the merged firm has a multidivisional structure and its output decisions are delegated to the manager of each division.

Specifically, it is supposed that a subset of merging firms, $s$, decides to form a single division; that is, they become a bigger firm and therefore cooperate with one another to maximize their joint profits. On the other hand, the remaining merging firms, $k-s$, behave as individual divisions in the multidivisional firm that results from the merger; that is, their managers choose the output to maximize each division's individual profits. Therefore, the merged firm has $k-s+1$ divisions that play an internal game in which each division competes with the others, and this fact gives the merged firm certain strategic advantages over non-merging firms.

In summary, it is assumed that the merged entity plays a mixed strategy in which some divisions maximize their joint profits, as in the traditional models, and other divisions maximize their individual profits, following Creane and Davidson (2004) and Huck et al. (2004). Concretely, it is proved that this internal organization of production in the merged entity is optimal for the merged entity. Therefore, the paper contributes to the existing literature a new way of restructuring internal production that is optimal for the merged entity.

Our hypothesis about the specific way in which the merged entity organizes its internal production is very hard to observe and measure and therefore difficult to test. However, in many cases, merging firms stay as independent decision-making units governed by a joint headquarters, as remarked by Huck et al. (2004). Specifically, as tested by Hubbard and Palia (1999), firms acquiring other firms retain certain target management, and usually, as justified empirically by Prechel et al. (1999) and Zey and Swenson (1999), merging firms become affiliates in a holding company, with some affiliates having the discretion to make independent decisions. Concrete examples of the above behaviour are the bank merger in Spain between the Bank of Santander and the Central-Hispano Bank (see Barcena-Ruíz and Garzón, 2000) and many mergers between car producers, for example those between Volvo and Ford and between Daimler and Chrysler (see Huck et al., 2004). 
The purpose of this paper is to investigate how the above assumption affects some traditional results of horizontal mergers in quantity-setting games. Concretely, assuming that the multidivisional firm formed by a merger sets its number of divisions optimally, it is proved that the number of merging firms necessary for a profitable merger is lower in our model, supposing both simultaneous and sequential competition, than in the traditional Salant et al. (1983) model; furthermore, it is shown that the optimal number of cooperating divisions of the multidivisional firm formed by the merger is lower assuming simultaneous decisions between merging firms than in the sequential game. Finally, it is proved that the welfare level after the merger is always higher than in the traditional Salant et al. (1983) model.

The merger lowers the market competition and therefore increases individual firms' profits. By preserving some merged firms as independent divisions, the merged entity captures their profits, and as a consequence the merger is more profitable than in the traditional Cournot model. Therefore, the number of merging firms that is needed to have a profitable merger is lower in our model than in the traditional ones. This internal organization of production in the merged entity, which, as remarked, is optimal for the merged entity, renders the merger more profitable than in the traditional Cournot model and contributes to a better understanding of merger activity.

The paper is organized as follows. Section II presents the basic model. In section III, Salant et al.'s (1983) results are presented and compared with those obtained in our model, assuming that merged firms take decisions both simultaneously and sequentially. Finally, section IV presents the main conclusions of the paper.

\section{The basic model}

Let us take as a reference an oligopoly model of $n$ firms that produce a homogeneous good. Quantity competition is assumed among firms, and, for simplicity, it is supposed that every firm has the same technology with no fixed costs and constant and equal zero marginal costs.

Given the above assumptions, each firm's profit is given by its overall income, that is, 


$$
\Pi_{i}=P x_{i}, i=0, \ldots, n,
$$

$P$ is the market price and $x_{i}$ the output of the ith firm.

Consumers are assumed to have quadratic utility functions, which are additively separable and linear in a competitive numeraire good. In this case, consumers' utility function is given by:

$$
U(Q)=Q-\frac{1}{2} Q^{2}
$$

where $Q=\sum_{i=1}^{n} x_{i}$, then, the inverse demand function is given by

$$
P=1-Q
$$

Therefore, consumers' surplus is given by

$$
C S=U(Q)-P Q=1 / 2 Q^{2},
$$

Social welfare is measured as the sum of consumers' surplus and firms' profits and is given by:

$$
W=C S+\sum_{i=1}^{n} \Pi_{i}
$$

Let us take, as an anchor case, the premerger scenario. In this case, we use the standard Cournot model and the assumed output competition results in the following equilibrium values:

$$
x_{i}^{B}=\frac{1}{n+1}, \quad \Pi_{i}^{B}=\frac{1}{(n+1)^{2}}, C S^{B}=\frac{n^{2}}{2(n+1)^{2}}, W^{B}=\frac{n(n+2)}{2(n+1)^{2}},
$$

where the superscript ${ }^{B}$ denotes the scenario before any merger between firms.

\section{Merging firms' strategies and merger effects}

The existing literature on horizontal merger profitability in Cournot oligopoly models states that a merger could be profitable for the merging 
firms under certain hypotheses. Particularly, Salant et al. (1983) stated that at least $80 \%$ of firms in the industry have to merge to make the merger profitable and that, even in this case, the merger would be harmful from a welfare point of view.

The purpose of this section is to qualify the above results by proving that the number of firms needed to have a profitable merger is lower than that stated by Salant et al. (1983). Furthermore, this section verifies that a merger is less welfare harmful than in the traditional model. To prove these results, similarly to Huck et al. (2004) and Creane and Davidson (2004), it is assumed that a merger is not strictly a fusion; that is, it is not just a bigger firm but a more complex organization made up of several divisions. Therefore, merging firms, instead of cooperating with each other and choosing the output to maximize their joint profits, could exploit the strategic possibilities that result from having several divisions or subsidiaries.

Specifically, it is assumed that the merged entity allows some divisions to act individually. In this case, the merged entity has two types of divisions: those divisions that set their output to maximize their joint profits - that is, they become a single division in the multidivisional firm formed by the merger - and those divisions that set their output to maximize their individual profits - that is, they behave as individual divisions in the merged entity.

To develop the analysis, the section is organized as follows. Firstly, as an anchor case, the traditional Salant et al. (1983) model is considered. Secondly, it is assumed that the merged entity allows some divisions to act individually. Finally, similarly to Creane and Davidson (2004) and Huck et al. (2004), it is considered that the strictly merged divisions have an informational advantage over the individual optimizer divisions.

\subsection{Traditional model}

Taking as a reference the basic oligopoly model set in section II, it is assumed that $k$ firms decide to merge. In this case, after the merger, Cournot competition leads to the following equilibrium values:

$$
x_{i}^{A}=\frac{1}{n-k+2}, \Pi_{i}^{A}=\frac{1}{(n-k+2)^{2}}, C S^{A}=\frac{(n-k+1)^{2}}{2(n-k+2)^{2}},
$$




$$
W^{A}=\frac{n(n-2 k+4)+k(k-4)+3}{2(n-k+2)^{2}},
$$

where the subscript ${ }^{A}$ represents the situation after the merger.

The merger will be profitable if it is verified that.

$$
\Pi_{i}^{A}-k \Pi_{i}^{B}>0 \Leftrightarrow k^{A}>n-\frac{1}{2} \sqrt{4 n+5}+\frac{3}{2}
$$

That is, mergers are not beneficial for the merging firms unless they include the vast majority of industry participants.

\subsection{Some divisions act individually: The simultaneous game}

In this part, as in the above subsection, it is assumed that $k$ firms decide to merge; furthermore, in this case, it is assumed that the merged entity allows some divisions to set their output individually. Specifically, it is assumed that $s$ firms merge by forming a single division and the other firms in the merged entity, that is, $k-s$ divisions, set their output to maximize their individual profits.

Therefore, after the merger, there are $n-s+1$ firms in the market: $n-k$ non-merging firms, $k-s$ individual profit optimizer divisions and one division that results from the fusion of $s$ firms. In this case, following Baye et al. (1996) and Schwartz and Thompson (1986), it is assumed that the manager of each division in the merged entity chooses the output to maximize his or her division's profits.

In this case, the market equilibrium, derived from Cournot competition between both merging and non-merging firms, is given by the following values:

$$
\begin{aligned}
x_{i}^{A I C} & =\frac{1}{n-s+2}, \Pi_{i}^{A I C}=\frac{1}{(n-s+2)^{2}}, C S^{A I C}=\frac{(n-s+1)^{2}}{2(n-s+2)^{2}}, \\
W^{A I C} & =\frac{n(n-2 s+4)+s(s-4)+3}{2(n-s+2)^{2}},
\end{aligned}
$$

where the subscript ${ }^{A I C}$ represents the situation after the merger, assuming both that some divisions act individually and that Cournot competition exists. The above expressions show that the market equilibrium depends 
on the existing relationship between the number of firms in the market, $n$, and the number of cooperating divisions in the merging entity, $s$.

Let us assume that the merging entity decides its number of cooperating divisions optimally. In this case, the following results can be stated:

\section{Result I}

If $k>\frac{n+1}{2}$, it will be optimal for the merged entity to have two kinds of divisions: those that maximize joint profits and those that maximize individual profits.

\section{Proof}

In this case, let us assume that the merged entity sets $s$ to maximize the merged entity's joint profits, that is, ;

$$
\frac{\partial\left(\Pi^{A I C}+(k-s) \Pi^{A I C}\right.}{\partial s}=0 \text {, by solving, the optimal } s \text { is derived and it is }
$$

given by $s^{A I C}=2 k-n$. Therefore, it is verified that $s^{A I C}>1 \Leftrightarrow k>\frac{n+1}{2}$, which proves the result.

\section{Result II}

The number of merging firms that is needed to have a profitable merger is lower in our model than in the traditional Salant et al. (1983) model.

\section{Proof}

In this case, the merger would be profitable for the merging firms if it is verified that. $\Pi_{i}^{A I C}+(k-s) \Pi_{i}^{A I C}-k \Pi_{i}^{B}>0$. Solving, it can be stated that the merger is profitable if it is verified that $k^{A I C}>\frac{n+1}{2}$, furthermore, it is verified that $k^{A I C}<k^{A} \forall n>1$, which proves the result. 


\section{Corollary I}

The merger will be profitable for the merging parties if it includes at least $50 \%$ of the industry's firms.

This reduction in the number of merging firms necessary for a merger to be profitable is due to the fact that the fusion of some divisions $(s)$ is profitable for the remaining $(k-s)$ divisions in the multidivisional firm resulting from the merger and that the global profits of the merged entity therefore increase. As a result, the number of merging firms needed to guarantee a profitable merger is lower in our model than in the traditional Salant et al. (1983) model.

The above result is related to the existing literature on the subject. Specifically, some papers have tried to identify sufficient conditions by which certain mergers should be approved; see Cheung (1992), Farrell and Shapiro (1990) and Levin (1990), among others. These papers show that, in the absence of cost synergies, what matters for a profitable merger is not the number of merging firms but the merger's market share.

\section{Result III}

Assuming that $s$ is set optimally, that is, $s^{A I C}=2 k-n$ the merger will be harmful to consumers and profitable for non-merging firms. Furthermore, it will be more profitable from a welfare point of view than in the traditional Salant et al. (1983) model.

\section{Proof}

The above result can be obtained directly by comparing the market equilibria values before and after the merger. Specifically, the following relationships are derived: $\Pi^{A I C}-\Pi^{B}>0 ; C S^{A I C}-C S^{B}<0$ and $W^{A I C}-W^{B}>0$, which prove the result.

It is well known that mergers increase market concentration and therefore firms' profits increase and consumers' surplus decreases. However, in our model, as some divisions behave as individual profit optimizers, the merger increases both their output and their profits. Furthermore, as a con- 
sequence, the negative effect on consumers is lower than in the traditional literature, and, as a result, the merger is less harmful from a welfare point of view than in the traditional Salant et al. (1983) model.

\subsection{Some divisions act individually: The sequential game}

Once more, it is assumed that the manager of each division sets the output to maximize his or her division's profit. However, similarly to Creane and Davidson (2004) and Huck et al. (2004), it is assumed that some managers have an informational advantage with respect to other managers. Consequently, although the multidivisional firm has no informational advantage with respect to non-merging firms, the merger gives some divisions a firstmover advantage with respect to other divisions.

Specifically, it is assumed that the single division that results from the fusion of $s$ individual firms is a 'partial leader' of the game; that is, it acts as a Stackelberg leader against the other $k$-s divisions, which are 'partial followers'. However, as indicated, the multidivisional firm that results from the merger and the non-merging firms are Cournot competitors.

The above game can be solved by backwards induction as follows. First, the $k$-s Stackelberg followers set the output to maximize their individual profits. In this case, their reaction function can be derived as follows:

$$
\frac{\partial\left(\Pi^{P F}\right)}{\partial x^{P F}}=0 \Rightarrow x^{P F}=\frac{1}{k-s+1}\left(1-(n-k) x^{N M}-x^{P L}\right)
$$

where the superscripts ${ }^{P F},{ }^{N M}$ and ${ }^{P L}$ refer to partial followers, non-merging firms and the partial leader, respectively.

The partial leader, knowing the partial followers' reaction functions, sets its output to maximize its profits, which enables us to derive its reaction function as follows:

$$
\frac{\partial\left(\Pi^{P L}\right)}{\partial x^{P L}}=0 \Rightarrow x^{P L}=\frac{1}{2}\left(1-(n-k) x^{N M}\right)
$$

The non-merging firms' reaction function can be derived similarly and is given by: 


$$
x^{N M}=\frac{1}{n-k+1}\left(1-(k-s) x^{P F}-x^{P L}\right)
$$

Solving the above reaction functions, the market equilibrium is derived and is characterized as:

$$
\begin{aligned}
& x^{N M}=x^{P F}=\frac{1}{n-2 s+k+2}, x^{P l}=\frac{1+k-s}{n-2 s+k+2}, \\
& \Pi_{i}^{N M}=\Pi_{i}^{P F}=\frac{1}{(n-2 s+k+2)^{2}}, \Pi^{P l}=\frac{1+k-s}{(n-2 s+k+2)^{2}}, \\
& \mathrm{CS}^{A I S}=\frac{(n-2 s+k+1)^{2}}{2(n-2 s+k+2)^{2}}, \\
& \mathrm{~W}^{A I S}=\frac{n(n+2 k-4 s+4)+k(k-4 s+4)+s(4 s-8)+3}{2(n-2 s+k+2)^{2}}
\end{aligned}
$$

where the subscript ${ }^{A I S}$ represents the situation after the merger, assuming both that some divisions act individually and that Stackelberg competition exists.

Once more, the market equilibrium depends on the existing relationship between $n, k$ and $s$. Assuming that the number of cooperating divisions, $s$, is set optimally, the following results can be stated:

\section{Result IV}

Assuming that merged firms take their decisions sequentially, if it is verified that $k>\frac{n+2}{3}$, it will be optimal for the merged entity to adopt two kinds of divisions: those that maximize joint profits and those that maximize individual profits. Furthermore, the optimal number of cooperating divisions that maximize joint profits after the merger is greater in the sequential than in the simultaneous game. 


\section{Proof}

Once more, the multidivisional firm formed by the merger sets $s$ to maximize the merged entity's joint profits, that is, $\frac{\partial\left(\Pi^{P L}+(k-s) \Pi^{\mathrm{PF}}\right.}{\partial s}=0$, and, solving, the optimal $s$ is derived and is given by $s^{A I S}=\frac{1}{2}(3 k-n) ;$ it is also verified that. $s>1 \Leftrightarrow k>\frac{n+2}{3}$, Furthermore, $s^{A I S}-s^{A I C}=\frac{1}{2}(n-k)>0$, which proves the result.

The optimal number of cooperating divisions increases assuming sequential competition, because, although neither partial followers' divisions nor non-merging firms change their output, the partial leader increases both its output and its profits.

\section{Result $V$}

Assuming that $s$ is set optimally, that is, $s^{A I S}=\frac{1}{2}(3 k-n)$ the number of merging firms needed to have a profitable merger assuming sequential competition is the same as in the simultaneous game and therefore lower than in the traditional Salant et al. (1983) model.

\section{Proof}

The merger is profitable for the merging firms if it is verified that, $\Pi^{P L}+(k-s) \Pi^{P F}-k \Pi^{B}$ assuming optimal $s$ and, solving in $k$, the following result is obtained: $k^{A I S}>\frac{n+1}{2}$, Furthermore, it is verified that $k^{A I C}=k^{A I S}<k^{A}, \forall n>1$, which proves the result.

This result is due to two opposed effects: first, the partial leader's profits increase, which reduces the number of merging firms needed to have a profitable merger; second, the optimal number of cooperating firms $(s)$ increases, and, as a consequence, the number of partial fol- 
lowers $(k-s)$ decreases, which increases the number of merging firms needed to have a profitable merger. The two effects offset each other; as a result, the number of merging firms $(k)$ is the same in the two considered contexts.

Taking into account the above two results, the following corollary can be stated:

\section{Corollary}

The number of divisions of the multidivisional firm formed by the merger is lower in the sequential game than in the simultaneous one.

\section{Result VI}

If $s$ is set optimally, it is verified that partial followers' profits, non-merging firms' profits, consumers' surplus and welfare are the same under both a simultaneous and a sequential game. However, the partial leader's profits are greater in the sequential game than in the simultaneous one.

\section{Proof}

The result is proved directly by comparing the above-mentioned values in the two considered scenarios, and the following results are obtained:

$$
\begin{aligned}
& \Pi^{P L}-\Pi^{A I C}>0, \Pi^{P F}-\Pi^{A I C}=0, \Pi^{N M}-\Pi^{A I C}=0 \\
& C S^{A I S}-\Pi^{A I C}=0, \mathrm{~W}^{A I S}-\mathrm{W}^{A I C}=0
\end{aligned}
$$

which prove the result.

As indicated, in the sequential game, the partial leader's output increases and both partial followers and non-merging firms do not change their output, $s$ increases and the number of partial followers decreases. However, neither the overall market output nor the equilibrium price varies, which justifies the result. 


\section{Concluding remarks}

This paper analyses the effects on the market equilibrium derived from a multilateral horizontal merger assuming both that a multidivisional firm is formed by the merger and that this multidivisional firm delegates output decisions to the manager of each division. These hypotheses give the merged firm strategic advantages over outsiders, and this fact has important implications for the traditional literature on horizontal mergers in quantity-setting games.

Specifically, it is proved that, from the merged firm's point of view, it could be optimal to organize its production according to two types of divisions: those that maximize their joint profits and those that maximize their individual profits. To the best of our knowledge, this is an original contribution to the existing literature on the subject. Particularly, it is proved that the optimal number of divisions in the multilateral firm resulting from the merger is lower when assuming simultaneous than when assuming sequential competition between merging firms.

In this context, it is proved that the number of merging firms needed for a merger to become profitable, assuming both simultaneous and sequential competition, is lower in our model than in the seminal paper by Salant et al. (1983). Furthermore, supposing that the merged firm sets the number of divisions optimally, it is proved that the merger is both sustainable and more beneficial, from a welfare point of view, than in the traditional Salant et al. (1983) model.

In summary, the paper complements the existing literature on mergers by proving that, in the stated model, a merger has different effects on relevant variables from those stated in the traditional literature, which could have important policy-making implications.

\section{References}

Barcena-Ruíz, J. C. and M. B. Garzón (2000). "Corporate Merger, Organizational Form, and Control of Labor". Spanish Economic Review, v. 2, 129-44.

Baye, M., K. Crocker and J. Ju (1996). "Divisionalization, Franchising, and Divestiture Incentives in Oligopoly". American Economic Review, v. 86, 223-36.

Cheung, K. F. (1992). "Two Remarks on the Equilibrium Analysis of Horizontal Mergers". Economics Letters, v. 40, 119-23. 
Creane, A. and C. Davidson (2004). "Multidivisional Firms, Internal Competition, and the Merger Paradox". Canadian Journal of Economics, v. 37, 951-77.

Daughety, A. (1990). "Beneficial Concentration". American Economic Review, v. 80, 107-26.

Escrihuela-Villar, M. and R. Faulí-Oller (2008). "Mergers in Asymmetric Stackelberg Markets". Spanish Economic Review, v. 10, 279-88.

Farrell, J. and C. Shapiro (1990). "Horizontal Merger: An Equilibrium Analysis". American Economic Review, v. 80, 107-26.

Fauli-Oller, R. (1997). "On Merger Profitability in a Cournot Setting". Economics Letters, v. $54,75-9$.

González-Maestre, M. A. and J. López Cuñat (2001). "Delegation and Mergers in Oligopoly". International Journal of Industrial Organization, v. 19, 1263-79.

Hubbard, R. G. and D. Palia (1999). "A Reexamination of Conglomerated Merger Wave in the 1960s: An Internal Capital Markets View”. Journal of Finance, v. 54, 1131-52.

Huck, S., K. A. Konrad and W. Müller (2004). "Profitable Horizontal Mergers without Costs Advantages: The Role of Internal Organization, Information and Market Structure". Economica, v. 71, 575-87.

Levin, D. (1990). "Horizontal Merger. The 50-Percent Bench-Mark". American Economic Review, v. $80,1238-45$.

Méndez-Naya, J. (2014). "Sustentabilidad de las Fusiones, Asimetrías de Información y Estrategias de las Empresas No Fusionadas". El Trimestre Económico, v. LXXXI-I (321), 227-40.

Perry, M. K. and R. H. Porter. (1985). "Oligopoly and the Incentives for Horizontal Mergers". American Economic Review, v. 75, 219-27.

Prechel, H., J. Boies and T. Woods (1999). "Debt, Mergers and Acquisitions, Institutional Arrangements and Change to the Multilayered Subsidiary Form". Social Sciences Quarterly, v. 80, 115-35.

Salant, S., S. Switzer and R. J. Reynolds (1983). "Loses from Horizontal Merger: The Effects of an Exogenous Change in Industry Structure on Cournot-Nash Equilibrium". Quarterly Journal of Economics, v. 48, 185-200.

Schwartz, M. and E. A. Thompson (1986). "Divisionalization and Entry Deterrence". Quarterly Journal of Economics, v. 101, 307-22.

Zey, M. and T. Swenson (1999). "The Transformation of the Dominant Corporate Form from Multidivisional to Multisubsidiary: The Role of the 1986 Tax Reform Act". Sociological Quarterly, v. 40, 241-67.

\section{About the author}

José Méndez-Naya -jmn@udc.es

Universidade da Coruña, Corunã, Spain.

ORCID: http://orcid.org/0000-0002-1153-4441.

\section{About the article}

Submission received on June 12, 2017. Approved for publication on March 19, 2018. 